\title{
The Turbulent End of an Era in Bolivia: Contested Elections, the Ouster of Evo Morales, AND the Beginning of a Transition Towards an Uncertain Future*
}

\author{
El final turbulento de una era en Bolivia: elecciones controvertidas, la \\ caída de Evo Morales y el comienzo de una transición hacia un futuro \\ incierto
}

\author{
JONAS WOLFF \\ Peace Research Institute Frankfurt (PRIF), Germany
}

\begin{abstract}
In Bolivia, the year 2019 marks the end of an era: In November, after almost 14 years in power, Evo Morales was forced to prematurely leave the presidency and, shortly thereafter, also the country. This dramatic event was preceded by contentious elections, allegations of electoral fraud, massive post-electoral protests, and the switching of sides by the police and the military. Rather than pacifying the situation, Morales' resignation led to a further escalation of the conflict, involving violent clashes between protesters and security forces. In the end, however, a negotiated solution of the crisis was reached that enabled the controversial interim president Jeanine Áñez to call new elections. In an attempt to make sense of this remarkable chain of events, the article (1) summarizes key causes that have made the once invincible Movimiento al Socialismo (MAS) government so vulnerable and (2) analyzes the October elections as well as the sociopolitical dynamics that unfolded afterwards with a focus on key controversies surrounding the elections (electoral fraud?) and the fall of Morales (a coup?). Finally, (3) the article briefly assesses the dynamics under the current interim government and looks at the forthcoming general elections, which are scheduled for 6 September 2020.
\end{abstract}

Keywords: Bolivia, Evo Morales, democracy, elections.

\section{RESUMEN}

En Bolivia, el año 2019 marcó el fin de una era: en noviembre, tras casi 14 años en el poder, Evo Morales fue forzado a dejar prematuramente la presidencia y, poco después, también el país. Este acontecimiento dramático fue precedido por elecciones controvertidas, denuncias de fraude electoral, protestas postelectorales masivas y el cambio de bando de la policía y las Fuerzas Armadas. En lugar de calmar la situación, la renuncia de Morales provocó una nueva escalada del conflicto, con enfrentamientos violentos entre los manifestantes y las fuerzas de seguridad. Sin embargo, finalmente se llegó a una solución negociada de la crisis que permitió a la polémica presidenta interina Jeanine Áñez convocar nuevas elecciones. En un intento por entender esta extraordinaria cadena de acontecimientos, el artículo (1) resume las principales causas que han hecho tan vulnerable al otrora invencible gobierno del Movimiento al Socialismo (MAS) y (2) analiza las elecciones de octubre, así como la dinámica sociopolítica que se desarrolló después, centrándose en las principales controversias en torno a las elecciones ( ¿fraude electoral?) y la caída de Morales (igolpe de estado?). Finalmente, (3) el artículo evalúa brevemente la dinámica bajo el actual gobierno interino y considera las próximas elecciones generales previstas para el 6 de septiembre de 2020.

Palabras clave: Bolivia, Evo Morales, democracia, elecciones. 


\section{INTRODUCTION}

There is no doubt what 2019 will be remembered for in Bolivia: the fall of longterm president Evo Morales and, thus, the end of an era. After almost 14 years in power, in November 2019, Morales was forced to resign after contentious elections, serious charges of electoral fraud, massive antigovernment protests and the switching of sides by the national police and the military. As a consequence, social conflict escalated only further, but eventually a negotiated solution of the post-electoral crisis was reached that enabled the contested interim government led by the conservative politician Jeanine Áñez to call new elections. Originally planned for 3 May 2020, these however were later postponed due to the COVID-19 pandemic and are currently scheduled for 6 September.

Against this background, the main part (III) of the following review of the year 2019 in Bolivia focuses on the dramatic events surrounding the October elections. In analyzing the elections themselves and the sociopolitical dynamics that unfolded afterwards, I will particularly assess two key controversies that concern the elections and the fall of Morales: Was there electoral fraud? Was there a coup? In order to provide some context to this analysis, the following section (II) summarizes key causes that help explain the sudden fall of the MAS government. In the final section (IV), I briefly assess the dynamics under the current interim government and look at the forthcoming general elections.

\section{SETTING THE STAGE: BOLIVIA BEFORE THE OCTOBER ELECTIONS}

Much has already been written about the causes that explain why a government and a president that appeared so invincible for so long fell the way they did. In this article, I can only briefly summarize key dimensions and arguments in order to provide some context to the analysis in Section III.

The most important trigger of the crisis and eventual fall of Evo Morales was certainly political. It concerned the contested question of whether Morales, after already being reelected twice (2009 and 2014), could run for yet another presidential election in 2019 (see Barrios 2017). On 21 February 2016, a narrow majority of the voters rejected the proposal to change the constitution to allow Morales and his vice president Álvaro García Linera to run again. ${ }^{1}$ The MAS decided to ignore this popular vote and pushed through a constitutional reinterpretation by the Tribunal Constitucional Plurinacional, which in 2017 declared term limits for elected offices as a breach of the universal right to political participation as enshrined in the American Convention on Human Rights.

Two scandals certainly influenced this outcome: a major corruption case concerning the Fondo Indigena and direct accusations against the president because of his links to Gabriela Zapata, a former partner of Morales and alleged mother of a son, "who had illegally benefited from large sums of money from contracts with the state" (Zegada 2019: 156). 
This provoked a significant wave of protests "in defense of democracy", which mobilized, in addition to the political opposition, the urban middle classes, but also received important support from the popular sectors and generally undermined the (perceived) legitimacy of Evo Morales and his government (see Molina 2019; Zegada 2019: 150-152; Brockmann 2020; Mayorga 2020). The controversy over the Morales candidacy meant that the government essentially lost the support that had remained among the traditional (non-indigenous) urban middle classes, while also disappointing parts of the popular sectors, including among the emerging middle class with indigenous roots. This already widespread rejection of the very candidacy of Morales as well as the experiences and networks constructed during these protests formed the basis on which the allegations of electoral fraud could trigger such an immediate response (see below).

The political cleavages that became manifest between 2016 and 2019, however, also had an economic dimension. With the end of the commodities boom, the peculiar model of post-neoliberal development pursued by the MAS government had become increasingly unviable. As I have argued elsewhere, this in particular concerned the combination of "an emphasis on state-led development and social inclusion with a supportive hands-off approach towards private business in key strategic areas (such as most notably, export-oriented agribusiness)" (Wolff 2019: 120). Originally, the reliance on primary sector-based, neo-developmentalist policies had enabled a de facto alliance between the MAS government, large parts of the economic elites and important segments of the population, even if it meant increasing conflict with erstwhile allies of the MAS among the indigenous population (Arze and Gómez 2013; Mayorga 2016). Yet, the alliance between the MAS and Bolivia's traditional economic elites was merely tactical in nature and, thus, vulnerable to shifting correlations of forces (Wolff 2019: 119-120). At the same time, the powerful alliance that had brought the MAS to power in the first place and was key to its defense during the first years of the government was increasingly fragmented and partially demobilized (Mayorga 2016: 214-219; Moldiz 2020: 31-32, 70-80, 96). The divisions within this sociopolitical alliance not only resulted from the government's disregard for collective indigenous rights and environmental issues, but also reflected distributive conflicts as in the case of Potosí (with a view to lithium extraction).

As a short-term factor, the dramatic rainforest wildfires that affected important parts of the Bolivian lowlands in the months preceding the elections arguably reinforced the above trends (Mayorga 2020: 12-13; Moldiz 2020: 96-98). On the one hand, the timid response of the MAS government received much criticism. On the other, the wildfires were partly attributed to the MAS policy of expanding the agricultural frontier (see Brockmann 2020: 39-40).

At the international level, the gradual weakening of the MAS hegemony in Bolivia was accompanied by a much more pronounced "turn to the right" in a series of important countries, including in Argentina, Brazil and the United States, as 
well as by the open crisis of the Maduro regime in Venezuela (Chiasson-LeBel and Larrabure 2019). This also meant a shifting correlation of forces within the Organization of American States (OAS), while regional organizations politically associated with the MAS government (such as UNASUR) virtually ceased to exist. Indeed, the OAS would play an important role in the crisis surrounding the October elections in Bolivia (see below). The extent to which the US government was actively involved is much more contested. While there is no doubt that the US government both explicitly and covertly supported the destabilization and removal of the MAS government as well as the incoming Áñez administration, existing evidence suggests that "domestic politics played a decisive role" (Farthing 2020: 5). ${ }^{2}$ In what follows, I will therefore focus on intra-Bolivian dynamics; an analysis of the role of US in this story will require a separate study.

\section{A TURBULENT MONTH: ELECTIONS, PROTESTS, AND THE END OF THE MORALES PRESIDENCY}

In this main section of the article, I will start by giving a brief overview of the elections and the post-electoral crisis that unfolded afterwards. Then, I will review two key controversies that concern the questions of whether and to what extent the 2019 presidential elections were fraudulent and whether the forced resignation of Evo Morales can be considered a coup.

\section{Overview of Key Developments}

General elections took place on 20 October 2019. Although, as mentioned, the very participation of then president Evo Morales as a candidate was heavily contested, the voting itself proceeded in a peaceful manner, without significant incidents (EU 2019: 32-33). Yet, tensions quickly escalated as preliminary results published by the Tribunal Supremo Electoral (TSE) on the evening of election day suggested that Morales might not win in the first round. Based on $83.8 \%$ of the votes as processed by the TSE's Preliminary Results Transmission System (TREP), Morales was reported to have received $45.71 \%$, easily surpassing the 40 percent threshold needed for a direct win. But, with $37.84 \%$ for Carlos Mesa, Morales would have failed to receive the ten percent lead over the second-ranked candidate that was also necessary to avoid a runoff. On this basis, Mesa publicly announced that a second round would have to take place, while Morales declared victory in the first round, arguing that the missing votes were mainly from rural areas in which support for the MAS was traditionally very high (EU 2019: 34-35; Johnston and Rosnick 2020: 14). In this context, the TSE decided to stop the TREP, a decision that would receive sharp criticism from 
international election observers as well as from the Bolivian opposition (see OAS 2019c: 9; EU 2019: 35). ${ }^{3}$ In response, the opposition started to mobilize.

When the publication of results from the TREP was resumed in the evening of 21 October, it showed Morales narrowly achieving the ten percent lead over Mesa. In response, the OAS mission issued a strong press release emphasizing an "inexplicable change" in the trend of the vote that "drastically modifies the fate of the election and generates a loss of confidence in the electoral process" (OAS 2019a). As anti-MAS protests escalated across the country, regional election offices were burned in several departments; pro-MAS protests, while remaining on a limited scale, similarly turned violent (see EU 2019: 38-39; Brockmann 2020: 41-46; Farthing 2020: 6-7; Mayorga 2020: 4-5). In the three weeks following the elections, Bolivia saw "a massive uprising of the urban sectors and the middle class of the population, which paralyzed all cities of the country, except for La Paz and El Alto, and managed to hinder the normal functioning of the country" (Molina 2019). But, as Molina (2019) adds, it was not only the usual suspects that mobilized against Morales: Given the widespread lack of trust in the TSE, which the tribunal exacerbated through its own actions, the allegation of fraud resonated also among traditional MAS supporters from the popular sectors and the indigenous population (see also Moldiz 2020: 99-100).

As the Crisis Group reported, these protests quickly took "an ugly turn": Clashes between opponents and supporters of Morales "led to several deaths"; violence escalated, "with properties belonging to Morales, his colleagues and his opponents burnt"; and, in the small town Vinto in the Cochabamba region, "opposition thugs marched a Morales-allied mayor barefoot through the streets, cut her hair and doused her in red paint." (Crisis Group 2019; see also IACHR 2019). Anti-MAS mobilization also saw a radicalization of the demands: from the initial call for a second round, through a claim for new elections, up to the point where only the resignation of Morales could satisfy the protestors (Mayorga 2020: 17). This dynamic was accompanied by a changing correlation of forces within the opposition movement. This is best symbolized by the marginalization of the centrist presidential candidate Carlos Mesa by the much more radical, conservative leader of the civic committee from Santa Cruz (Comité Pro Santa Cruz), Luis Fernando Camacho: Mesa had originally emerged as the "natural" protagonist from the elections, but Camacho quickly became the most visible face of the opposition to the MAS (Nugent 2019; Farthing 2020: 7; Moldiz 2020: 100-101). With the rise of Camacho and later Áñez, the conservative elites from the Bolivian lowlands (media luna) again took over the role of the central force confronting the MAS at the national level, a role they had gradually lost since 2008 .

Also, the vice president of the TSE, Antonio Costas, resigned in response to the suspension of the TREP, criticizing the decision but emphasizing that there was "no fraud" but "imperfections" (Johnston and Rosnick 2020: 16). 
Here is not the place to recount the series of events, ${ }^{4}$ but on 25 October, the TSE announced the final results, which confirmed Evo Morales' victory in the first round (see Table 1). In the Asamblea Legislativa Plurinacional, Bolivia's parliament, the MAS would have lost the two-thirds majority it has held since 2009, retaining however an absolute majority in both chambers (see Table 2). Yet, already before the announcement of these results, Morales had responded to the mass protests by inviting the OAS to verify the vote count. This audit took place, but protests from the opposition continued unabated. Finally, based on a preliminary audit report, the General Secretariat of the OAS on 10 November recommended annulling the electoral results and repeating the entire electoral process, while emphasizing that the constitutional mandate of President Morales should not be interrupted (OAS 2019b). In response, Morales agreed to hold new elections with a new TSE, but the situation only continued to escalate: In the absence of the (mutinied) police, which had mostly withdrawn from the streets in protest, the mobilization of both anti- and pro-MAS groups led to violent clashes, several houses of MAS representatives were burned down, and in response a series of MAS politicians resigned. In the afternoon, the head of the armed forces, General Williams Kaliman, publicly "suggested" that Morales step down in order to pacify the country (Mayorga 2020: 8). On the afternoon of 10 November, Morales and vice president García Linera resigned and, a day later, left the country for Mexico where they were granted political asylum (EU 2019: 40-41; Johnston and Rosnick 2020: 26).

Table 1. Official Results of the Annulled Presidential Elections of 20 October 2019

\begin{tabular}{lrr}
\hline & Share (in \%) & \multicolumn{1}{c}{ No. of votes } \\
\hline Evo Morales \& Álvaro García Linera (MAS-IPSP) & $47.08 \%$ & $2,889,359$ \\
Carlos Mesa \& Gustavo Pedraza (CC) & $36.51 \%$ & $2,240,920$ \\
Chi Hyun Chung \& Paola Barriga (PDC) & $8.78 \%$ & 539,081 \\
Óscar Ortiz \& Shirley Franco (21F) & $4.24 \%$ & 260,316 \\
Félix Patzi \& Lucila Mendieta (MTS) & $1.25 \%$ & 76,827 \\
Virginio Lema \& Fernando Untoja (MNR) & $0.69 \%$ & 42,334 \\
Ruth Nina \& Leopoldo Chui (PAN-BOL) & $0.65 \%$ & 39,826 \\
Víctor Hugo Cárdenas \& Humberto Peinado (UCS) & $0.41 \%$ & 25,283 \\
Israel Franklin Rodríguez \& Justino Román (FPV) & $0.39 \%$ & 23,725 \\
\hline
\end{tabular}

Source: Órgano Electoral Plurinacional (OEP), https:/ / www.oep.org.bo/elecciones-generales-2019. 
Table 2. Official Results of the Annulled Parliamentary Elections of 20 October 2019

\begin{tabular}{lcccccc}
\hline & \multicolumn{3}{c}{ Chamber of Deputies } & \multicolumn{2}{c}{ Senate } \\
\hline & $\begin{array}{c}\text { Plurinominal } \\
\text { (list) seats }\end{array}$ & $\begin{array}{c}\text { Uninominal } \\
\text { seats }\end{array}$ & $\begin{array}{c}\text { Special } \\
\text { reserved seats }\end{array}$ & Total & \\
\hline Movimiento Al Socialismo (MAS) & 18 & 42 & 7 & 67 & 21 \\
Comunidad Ciudadana (CC) & 33 & 17 & & 50 & 14 \\
Partido Demócrata Cristiano (PDC) & 9 & & & 9 & 0 \\
Bolivia Dice No (21F) & & 4 & & 4 & 1 \\
\hline
\end{tabular}

Source: Órgano Electoral Plurinacional (OEP), https:/ /www.oep.org.bo/elecciones-generales-2019.

According to the Bolivian constitution, the presidency of the country passes from the president to the vice president, to the president of the Senate and, finally, to the president of the Chamber of Deputies. The presidents of both chambers as well as the first vice president of the Senate, all from the governing MAS, however, had also resigned, under conditions which remain unclear. Based on a contested interpretation of the constitution and making use of the absence of the MAS majority in parliament, the opposition minority in parliament on 12 November elected second vice president Jeanine Áñez to become the new president of the Senate. On this basis, Áñez - a previously largely unknown, conservative opposition senator from Beni - assumed the presidency, promising new elections as soon as possible. The Tribunal Constitucional Plurinacional endorsed this move. The leadership of both the military and the police publicly promised their support of the interim government and now jointly moved into the streets to "pacify" the country, which saw a massive escalation of protests in support of Morales (see Brockmann 2020: 48-53; Moldiz 2020: 107-115).

The first two weeks of the Áñez presidency were characterized by a combination of open, partially violent confrontation on the streets and processes of negotiations that ultimately enabled a peaceful solution to the post-electoral crisis. On the one hand, MAS supporters mobilized against the alleged coup d'etat, propelled by their exiled leader. In addition to putting pressure on the new government by blocking roads and cities, pro-MAS groups also reportedly attacked police stations and homes of representatives of the anti-MAS protest movement (IACHR 2019; Farthing 2020: 9). ${ }^{5}$ But also the security forces, which had refrained from repressing the post-electoral protests against Morales, now acted decisively and, according to the IACHR (2019), at times with "excessive force". The Áñez administration issued a much-criticized decree, which ab-

With a view to the reports on pro-MAS groups that were supposedly about to ransack wealthier neighborhoods in cities like Cochabamba and La Paz, Linda Farthing reports that these fears mostly did not materialize: "There was some looting in the wealthy southern zone of $\mathrm{La} \mathrm{Paz}$, a fire set close to an affluent neighborhood in Cochabamba, and some 64 city-owned buses burned in La Paz. The press and popular discourse immediately pointed the finger at MAS militants, but several weeks later two leaders of the private local bus drivers unions were arrested for torching the buses." (Farthing 2020: 9) 
solved "members of the Armed Forces from criminal responsibility after taking part in operations to restore public order" (IACHR 2019). As an IACHR delegation to Bolivia reported, "joint operations carried out by the Armed Forces and the Police Force have resulted in the loss of human lives during different incidents throughout the country", including during what it calls "the massacres" that took place in Sacaba (Cochabamba) and Senkata (El Alto) (IACHR 2019). In addition to the at least 18 people who lost their lives in these two cases, the IACHR (2019) has identified another 18 people that had died since "the start of the crisis up to November 27". As Linda Farthing reports, "[o]ver two-thirds of the fatalities were working-class and Indigenous MAS supporters" (Farthing 2020: 9). She has also emphasized how the anti-MAS mobilization has revived openly racist discourses and attitudes (Farthing 2020: 10).

On the other hand, however, the Áñez government immediately embarked on negotiations with the MAS faction in parliament as well as with key social organizations. Reportedly, representatives of the Catholic Church and the European Union had facilitated the start of a multi-party dialogue already before Áñez took office (Vaca 2019). After tense days of difficult negotiations, which received support from the Catholic Church, the European Union, and the United Nations, amongst others, the new interim government and the MAS majority in parliament reached an agreement that enabled the adoption of a law that provided for the election of new members of the electoral court and the holding of new elections, ruling out another candidacy of Evo Morales (Layme 2019; La Razón 2019b). Reinforced by additional agreements with the Central Obrera Boliviana (COB) and the pro-MAS organizations allied in the Pacto de la Unidad, this agreement put an end to the violent escalation of conflict and enabled the preparation of new elections (Página SIETE 2019; Juárez 2019).

\section{The Question of Electoral Fraud}

Since Evo Morales responded to the preliminary report of the OAS by accepting new elections, the question of electoral fraud has receded into the background. On 24 November 2019, the legislative assembly (with the two-thirds majority still held by the MAS) unanimously approved a law that annulled the October elections (Brockmann 2020: 31). Still, the issue remains of more than theoretical interest. On the one hand, the extent and nature of electoral fraud is relevant for any evaluation of the involuntary end of the Morales presidency. On the other hand, a whole series of former electoral authorities are currently on trial, and Morales, García Linera and three former MAS ministers are being investigated for the alleged electoral fraud (Johnston and Rosnick 2020: 27; La Razón 2020b). In this section, I review the controversy, focusing on the most important studies and allegations.

As regards studies confirming electoral fraud, the final audit report of the OAS released on 4 December 2019 is certainly the key document (OAS 2019c). But 
several other studies have also presented evidence and/or statistical analyses that suggest electoral fraud (see, for instance, Chumacero 2019; Vacaflores 2019; Villegas et al. 2019; Newman 2020; Valdivia and Escobari 2020). The most important publications that refute the allegations of electoral fraud have come from the US-based Center for Economic and Policy Research (CEPR) (Long et al. 2019; Rosnick 2019; Johnston and Rosnick 2020). The study by Curiel and Williams (2020), which received much attention, was commissioned by the CEPR in order to verify their own statistical calculations. A further statistical analysis comes to similar conclusions (Idrobo et al. 2020). ${ }^{6}$ The most important allegations that are discussed in these studies include:

(1) the observation of manifold irregularities in the IT system and the chain of custody that made the vote count vulnerable to manipulation and fraud;

(2) actual evidence of manipulation and fraud;

(3) anomalous patterns and trends in the voting behavior or vote count identified through statistical analysis, which suggest the existence and extent of manipulation.

As regards the first issue, there is little doubt that serious irregularities compromised the IT network and its usage during the vote count (see OAS 2019c: 14-55; Vacaflor 2019: 13-16). It is contested, however, to what extent these irregularities were actually used to intentionally manipulate the vote (Johnston and Rosnick 2020: 65). ${ }^{7}$ The most serious problems, such as the usage of two servers that were not authorized for this purpose, concerned the preliminary results transmission system (TREP) only and not the official vote count (Cómputo Oficial) (Vacaflores 2019: 3; Johnston and Rosnick 2020: 58-64). The OAS (2019c: 15) emphasizes that the two systems were, in fact, connected, given that "more than $5 \%$ of the TREP tally sheet images went directly to the count". Still, this connection is obviously limited to a small share of the vote and a particular share that hardly fits the types of organized fraud that most observers suggest (Johnston and Rosnick 2020: 12). ${ }^{8}$ Given that most of the supposedly "deliberate actions that sought to manipulate the results of

Further studies arguing in this direction include Minoldo and Quiroga (2020) and Mebane (2019). Replies to the study by Curiel and Williams include Newman (2020), Nooruddin (2020) and Valdivia and Escobari (2020). For critical engagement with these papers, see Idrobo et al. (2020) and Rosnick (2020).

The same problem applies to the "deficient chain of custody" which, according to the OAS (2019c: 13), "did not guarantee that the elections materials were not manipulated and/or replaced" (see Johnston and Rosnick 2020: 45).

8 As the OAS (2019c: 46) reports, this direct transfer of tally sheets to the official vote count, on the one hand, concerned votes from overseas for which the physical documents would reach Bolivia later. Here, manipulation of the tally sheet images only would hardly suffice. In addition, it is late-coming votes from within Bolivia - and not votes from overseas - that is generally regarded as suspicious (OAS 2019c: 89). On the other hand, TREP images were used in the official count in cases in which tally sheets had been burned in the context of the post-electoral protests (OAS 2019c: 46). There is, however, "no evidence that electoral authorities or the Morales government were involved in the destruction of this material" (Johnston and Rosnick 2020: 10). In fact, as Johnston and Rosnick (2020: 10) emphasize, it is highly problematic that the OAS (2019c: 4-5) categorizes the burning of "an unknown number of tally sheets" among the "deliberate actions that sought to manipulate the results of the election", without discussing the crucial issue of authorship. 
the election" (OAS 2019c: 4-5) refer to the TREP, the critics of the OAS argue that the irregular practices observed (e.g., on the part of the private contractor in charge of managing the vote count) reflect human error and conflicts between key agencies and individuals involved in the vote count rather than intentional manipulation (see Johnston and Rosnick 2020: 12, 16, 63). The controversy, therefore, very much centers on the question of whether there is evidence of actual manipulation or fraud.

With a view to this second issue, the OAS audit analyzed 4,692 tally sheets, of which 226 (4.8\%) were found to have "irregularities" (OAS 2019c: 10). While these irregularities, such as the fact that a set of sheets was completed by one single individual, in and of themselves, do not prove fraud, it is noteworthy that the sum of the votes obtained by the MAS from these irregular sheets $(34,718)$ is "almost the exact number of votes needed to enable Morales to avoid a second round" (OAS 2019c: 10). ${ }^{9}$ Further studies contain evidence of modified or manipulated tally sheets, but without being able to assess the extent of actual fraud or its relevance for the national results (Chumacero 2019; Villegas et al. 2019; see also EU 2019: 34-41). Chumacero, for instance, identifies 950 tally sheets with mathematical errors (in the summation of votes). In these faulty sheets, the MAS wins disproportionately, but when comparing these sheets with other ones (without errors) from similar localities or polling stations, he finds that the differences in the voting behavior are minimal (Chumacero 2019: 28-30). Existing evidence on potentially manipulated tally sheets suggests three things. First, as Vacaflores argues, the fact that most possibly manipulated tally sheets come from five individual departments (Cochabamba, Potosí, Chuquisaca, Oruro and La Paz) suggests that fraud was not primarily committed in the digital sphere. Otherwise, we should expect an indiscriminate distribution of fraudulent tally sheets across the national territory (Vacaflores 2019: 24). Second, it is clear that there are serious issues with many tally sheets, which suggests that some kind of manipulation was plausibly taking place. Third, however, given that we simply lack the empirical information needed to systematically assess the extent of intentional manipulation, the latter can only be estimated by means of statistical plausibility probes of voting trends and patterns.

As mentioned above, the OAS (2019a) immediately criticized "an inexplicable change in trend", when the preliminary vote count TREP was resumed after the 24 hours stoppage. Whereas the OAS has never offered any empirical justification for this statement, a couple of statistical analyses has scrutinized the supposed change in the trend. The key question, here, is whether it is possible to predict the final results when extrapolating the voting pattern and trend until the TREP was temporarily halted at $83.85 \%$ of the vote count, or whether significant and

Johnston and Rosnick (2020: 11) emphasize that $78 \%$ of the voting centers in which these irregularities were recorded "are very small, with four or fewer voting tables" and argue that, therefore, the finding may simply reflect "a well-known phenomenon: in rural areas and smaller voting centers, it is not uncommon for one person to assist with the tally sheets." 
not otherwise explicable changes occur afterwards. In a statistical comparison of the results reported before and after the stoppage of the TREP, Diego Escobari and Gary Hoover estimate that the shutdown of the TREP increased the lead of Morales over Mesa by about 160,000 votes or about $2.6-2.7 \%$ of the valid votes, enough to secure MAS victory in the first round (Escobari and Hoover 2019: 4). While the authors quickly turn this finding into the claim "that the extent of the fraud is at least $2.67 \%$ of the valid votes" (Escobari and Hoover 2019: 1), the question remains whether this effect can also be explained by differences between the groups of voters whose ballots were counted before and after the shutdown of the TREP. Indeed, when allowing for systematic variation in local voting preferences, the estimated extent of fraud is reduced significantly. Controlling for differences at the precinct level, the effect remains statistically significant, but the extent $(0.21 \%)$ is no longer enough to change the result of the election (Escobari and Hoover 2019: 5). In another of their estimations, this effect is even reduced to "about 0.0602 percent of the total valid vote", as David Rosnick (2019: 9-10) has noted. Rosnick, therefore, argues that Escobari and Hoover ultimately confirm a CEPR report that had sharply criticized the OAS allegations. The latter study had found that, once missing votes are estimated based on already counted tally sheets from similar geographical entities, an extrapolation of the preliminary results of the TREP before the stoppage shows Morales winning with 10.09 percentage points (Long et al. 2019: 8-9). ${ }^{10}$

Another statistical study, however, which performs a similar type of analysis and also controls for precinct effects, finds that the difference between Morales and Mesa increases by almost 5\% in the final quintile of the votes counted (Chumacero 2019: 33). This gain corresponds to roughly 59,000 votes (or almost $1 \%$ of the valid votes), enough to secure Morales' victory in the first round. ${ }^{11}$ Yet, the statistical study conducted by Idrobo et al. (2020) raises doubts as to whether such MAS gains within precincts can be read as evidence of fraud. Their analysis suggests that the increase in the MAS share within precincts as the vote count progressed began well before the suspension of the TREP (Idrobo et al. 2020: 18-21). In an additional step, they almost exactly predict the final result by extrapolating the results reported before the shutdown drawing on the electoral results from the 2016 referendum (Idrobo et al. 2020: 23-27; see also Minoldo and Quiroga 2020).

The fact that the OAS audit report refrains from iterating the allegation of an inexplicable change in trend after the TREP shutdown suggests that the auditors themselves consider these estimates too debatable and uncertain. Implicitly backtracking from the charge that there was an "highly inexplicable change in trend" between the results at $84 \%$ and $95 \%$ of the vote count (OAS 2019a), the final audit report (as well as its preliminary version) identifies an "highly

The study by Curiel and Williams (2020) comes to similar conclusions.

Newman (2020: 21) comes to a roughly similar result (but see Rosnick 2020). 
improbable" trend in the last 5\% of the vote count (OAS 2019c: 86-94). ${ }^{12}$ In addition to the general trend in favor of the MAS, the analysis presented in the audit report shows a suspicious "discontinuity" or "break" in the trend line (the average cumulative national vote share) of both Morales and Mesa (OAS 2019c: 87-88). The report concludes that it is the "great divergence" between the shares of votes for Morales and Mesa in the final 5\% of the vote count, which is "unpredicted and unanticipated by any previous part of the election trends, that pushes MAS over the 10\% margin to outright victory" (OAS 2019c: 94; see also Nooruddin 2020). There are, however, at least two problems with this analysis. First, as Johnston and Rosnick (2020: 41) emphasize, the very data presented in the report shows that Morales's lead over Mesa was in fact higher in the penultimate $5 \%$ of the vote count than in the final $5 \%$. This is hardly in line with the notion of a "massive and unexplainable surge in the final $5 \%$ of the vote count" (OAS 2019c: 94). Idrobo et al. (2020: 13-18) also suggest that the alleged break in the trend is a statistical artifact only; at least, the discontinuity disappears when applying a different estimator. ${ }^{13}$ Second, while the OAS report discusses the potential counterargument that late-reporting polling stations might be from MAS strongholds, it only looks at the distribution at the departmental level (Johnston and Rosnick 2020: 34). As Minoldo and Quiroga (2020) have emphasized, the final 5\% of the tally sheets came disproportionately $(67 \%)$ from small precincts, in which the MAS generally did much better across the different departments. The OAS findings are, however, also confirmed by Chumacero's study, which compares the final 5\% of the tally sheets with previously reported tally sheets from similar local areas or precincts. In these final $5 \%$, the gap between the shares of the votes for Morales and Mesa is between 7.7 and 8.9 percentage points higher than should be expected (Chumacero 2019: 34-36). This is a significant difference, even if it merely corresponds to between 20,500 and 35,000 additional votes - not enough to bring Morales the necessary $10 \%$ lead. ${ }^{14}$

In sum, the 2019 elections in Bolivia were characterized by serious irregularities, which offered a series of opportunities for committing electoral fraud, both at the micro level and at the national stage. The evidence that confirms the actual extent of intentional manipulation is, however, more limited and contested. Given the fact that it was 0.57 percentage points only that decided over the supposed victory of Evo Morales in the first round, it is plausible that fraud

12 The failure of the OAS audit to systematically address (let alone confirm) the original claim of the OAS mission - that the decisive change in trend occurred precisely before, and not during, the final $5 \%$ of the vote count - lends support to those observers that have criticized the OAS mission for unduly and unfoundedly interfering in Bolivia's electoral process (see Long et al. 2019; Farthing 2020: 9). In addition to the mentioned statement, the (release of the) preliminary audit report, which contributed to triggering Morales's forced resignation, has also been criticized as offering rather "vague language" and lacking "clarity concerning its findings" (Johnston and Rosnick 2020: 25).

13 In addition, Idrobo et al. (2020: 13-15) point to serious inconsistencies in the data reported by the OAS.

14 Again, however, the above-mentioned counterargument applies that even changes over time within precincts may well reflect usual trends in voting and vote count behavior rather than fraud (Idrobo et al. 2020: 18-21). 
- however widespread or micro - made a decisive difference. But available evidence does certainly not prove any massive fraud. Most analyses that supposedly prove or refute electoral fraud focus on what happened after the TREP was temporarily suspended or even on the final $5 \%$ of the vote count. Statistical analyses suggest that potential fraud may make a difference of between 0 and 2.67 percentage points. Of course, it is impossible to refute the possibility that fraud was "already baked into the $84 \%$ of votes", which had been counted before the shutdown of the TREP (Valdivia and Escobari 2020). Yet, all the studies and statistical analyses that support the notion of electoral fraud indicate that irregular trends and patterns "began to develop massively after the TREP service was cut off" (Vacaflores 2019: 24). Given that also two quick counts as well as the internal assessment of the OAS confirmed the general tendency (EU 2019: 34), no one seriously doubts that Evo Morales actually won the first round. What has to be added, however, is that the electoral playing field was anything but level to begin with. In particular, as the report of the EU election observation mission notes, during the campaign the MAS made massive usage of state resources (state media outlets, public investment, state officials) (EU 2019: 18-20; see also Brockmann 2020: 35-40).

\section{The Coup Controversy}

For the MAS as well as many leftist international observers, the forced resignation of Morales was clearly a coup d'état. A declaration issued by the MAS leadership refers to "a civic-police coup" (un golpe cívico/policial). In emphasizing the role of the police, this statement adheres to the framing advanced by Morales as he publicly explained his resignation (MAS 2019). International observers, by contrast, stress the role of the military (see Grandin 2019; Natanson 2019). In an article signed by 300 international scholars, for instance, Greg Grandin argues that Morales' "coerced resignation" was "a military coup", "a constitutional interruption", which could hardly be justified by the alleged electoral fraud given that Morales had already accepted new elections. The "nature of the coup" became even clearer, Grandin adds, when MAS legislators were prevented from entering parliament, "on the day Senator Jeanine Áñez declared herself president" (Grandin 2019; see also Natanson 2019; Santos 2019). From within Bolivian MAS circles, Hugo Moldiz has emphasized the key role of both the police and the military: While the former actively joined the anti-government protests, the latter's decision of "non-intervention" effectively meant "paving the way for the coup plans" (Moldiz 2020: 101-102). Later, Luis Fernando Camacho's revelation that his father had coordinated with both the military and the police to ensure that they would not take actions against the protest movement lent further support to the idea of a coup (Farthing 2020: 7-8; Mayorga 2020: 9). Steven Levitsky and María Victoria Murillo, classify the fall of Morales as a "military coup" given that the elected president, "faced with a police and armed forces that abandoned their subordination to the president", was virtually "forced to resign" (2020: 6). 
Others acknowledge that there were coup-like elements involved, but emphasize that the whole story is much more complex. According to Stefanoni, "that the military 'suggests' the resignation of the president and puts the presidential sash on his successor looks pretty much like a coup." Still, he adds, the notion of a coup has to be put into context in order to make sense of "the complex sequence of events" (Stefanoni 2020). From a different political perspective, Michael Shifter assesses that "in very technical terms" the intervention of the armed forces turned the resignation of Morales into "a coup"; but politically, he argues, this coup can only be understood in the light of the electoral fraud committed by Morales and the MAS (Shifter 2019). Fernando Molina (2019), by contrast, rejects the notion of a coup and emphasizes that the argument that attributes the resignation of Morales only to the military's "suggestion" to resign tends to ignore a couple of things, such as the fact that also the leader of the Central Obrera Boliviana (COB), Juan Huarachi, asked Morales to step down, or that the resignation followed weeks of massive protests, including in regions (such as Potosí) and by social groups (such as the mine workers) that had traditionally supported the MAS. According to Molina (2019), the "primary cause" of Morales' downfall was the post-electoral popular uprising, and the "trigger" was "the police mutiny", which he traces back to dissatisfaction with lost privileges and disadvantages vis-à-vis the military.

On the other side of the political spectrum, the Secretary General of the OAS represents those that outright rejected the idea of a coup against Morales. Almagro stated that not the forced resignation of the elected president but the electoral fraud committed by the government and confirmed by the electoral court was a "coup d'ètat", or a "self-coup" (Mayorga 2020: 9). This notion of a "self-coup" is far-fetched to say the least, as Franz Barrios argues, given that "Evo did not interrupt, however illegal his moves were, anyone's mandate". Barrios, on his part, rejects the idea of a coup against Morales on other grounds: In defining a coup as necessarily directed against a constitutional order and arguing that the constitutional order had already been broken when Evo Morales was allowed to be elected for another term back in 2014, Barrios concludes that a coup was simply no longer possible. Instead, one should rather talk about a "restoration of the previously violated constitutional order" (Barrios 2019).

In discussing the conception of coup d'états, Barrios explicitly refers to the work of Jonathan Powell and Clayton Thyme. Based on a review of competing definitions, Powell and Thyme (2011) identify a definition that best fits the common usage of the term: A coup attempt "includes illegal and overt attempts by the military or other elites within the state apparatus to unseat the sitting executive" (2011: 252; emphasis in the original). Two features of this definition are of relevance here: First, forces from within the state apparatus have to play a key role; otherwise, Powell and Thyme argue, we would conflate coups with other types of anti-regime activities (such as civil wars and revolutions) in which the threat to the incumbents emerges from outside the regime (2011: 250-251). Second, while a coup not necessarily involves the use of violence, it does have to be 
illegal (2011: 251). The key criterion emphasized by Barrios (2019) is, however, explicitly not part of their definition: Coups do not have to be directed against a constitutional order. In fact, this option is not even discussed in the paper. ${ }^{15}$

As a consequence, the key issue remains the role of actors from within the state apparatus in the forced resignation of Morales. It is probably fair to say that the actions taken by the police and the military had coup-like features but do not entirely meet the above definition in a strict sense. ${ }^{16}$ At the same time, this is clearly only part of the story. In other regards, the chain of events very much resembles what has been dubbed "presidential falls" or "interrupted presidencies" in the comparative literature (Valenzuela 2004; Hochstetler 2006). ${ }^{17}$ In contrast to traditional coups, the premature interruption of presidential terms constitutes within-regime change, not regime breakdown. In the case of Bolivia, the fall of President Sánchez de Lozada in 2003 is a case in point. Empirically, as Kathyrn Hochstetler (2006) has shown, presidential falls across South America since the 1980s have been characterized by a central role of mass protests, sometimes but not always complemented by challenges to elected presidents from within the legislature. In rare cases, such as in the toppling of President Jamil Mahuad in Ecuador (2000), the military also played an active role. What is unusual about the most recent Bolivian case, however, is that the line of succession ended with a representative of the minority group in parliament. This contrasts with the usual pattern across the region: the taking over of the presidency by either elected vice presidents or legislative leaders representing parliamentary majorities (Hochstetler 2006: 402).$^{18}$ What makes the transition from Morales to Áñez look particularly undemocratic in substantive terms is that it openly and drastically contradicts the popular will as reflected in the party affiliation of the elected president and the composition of parliament. Still, procedurally speaking, it did not imply an open breach of the constitutional order,

15 Arguably this is the case because it would render the concept analytically useless, turning it into an openly political one: Before deciding on whether something could be called a coup, we would need a definite answer to the question whether there had been serious violations of the constitutional order in the recent past. Or, the other way round: As long as potential perpetrators of a coup can point to some reasonably plausible, preceding violation of the constitutional order, they could reject the charge of staging a coup. Empirically, most scholars do also consider a coup a coup even if it was directed against an openly unconstitutional order (e.g., a coup that unseats a head of state that, for its part, seized power by means of a coup).

16 The police mutiny was probably illegal but did not constitute an overt attempt to unseat the president (as in previous cases, the reasons officially given by the police referred to grievances in terms of wages and working conditions); the public declarations that preceded Morales' resignation represented such an overt attempt but were probably not illegal; and the supposed collusion between key anti-MAS groups and the security forces during the mass protests was obviously non-overt.

17 In emphasizing this part of the story, and downplaying the role of the military and the police, Roberto Laserna (2019) rejects the notion of a coup and rather identifies an "insurgency" or "insurrection", "which culminated in a legal succession".

18 When Carlos Mesa, who himself had taken over the presidency as Sánchez de Lozada's vice president after the latter's fall, stepped down in 2005, the then president of Bolivia's Supreme Court, Eduardo Rodríguez Veltzé, took over the presidency in order to organize new elections. In contrast to Áñez, however, Rodríguez Veltzé was quite plausibly a non-partisan caretaker president and did certainly not represent the then opposition. 
as confirmed by the constitutional court's official endorsement of the transition from Morales to Áñez. ${ }^{19}$

Another issue that is of relevance concerns the aftermath of the supposed coup. An important argument against the notion of a coup was that the interim government did not, in fact, aim at seizing power, but merely at filling a power vacuum in order to enable the organization of a new electoral process (Mesa 2020). In this regard, again, the balance is mixed. On the one hand, the Áñez government eventually accepted the MAS majority in parliament and successfully negotiated the legal and institutional changes needed for the convocation of new elections. On the other hand, as will be discussed in the next section, the government has clearly gone beyond acting like a caretaker administration that would limit its activities to the absolutely necessary and remain as politically neutral as possible. The most obvious example of such a transgression is the very candidacy of Jeanine Áñez, a move that, according to opposition candidate Carlos Mesa, has validated the claims "that there was, in fact, a coup d'état in Bolivia" (Mesa 2020).

\section{AN UNCERTAIN TRANSITION: THE INTERIM GOVERNMENT AND THE PATH TOWARDS NEW ELECTIONS}

In this section, I summarize key features that have characterized the Áñez administration during its first months. Given that the focus of this article is on the year 2019, I will only present general lines and overall tendencies here. In the final part, I will look ahead to the new elections by turning to recent opinion polls. But this outlook will remain very tentative only, given the current COVID-19 crisis and the uncertainty of whether the postponed elections will actually take place in September as currently scheduled.

\section{The Áñez Administration: Much More Than a Caretaker Government}

Upon assuming office, Áñez recognized her "strictly provisional" presidential mandate and promised to focus on the preparation of new elections (La Razón 2019a). But, as already emphasized, the interim government almost from the start broke with this promise, making it clear that the aim was really to take Bolivia back to the pre-MAS era (Mayorga 2020: 2-3). At the symbolical level, most notably, the new interim president Ãñez echoed Camacho in emphasizing that the change in government actually amounted to bringing the bible back to the presidential palace (Nugent 2019).

19 Even if the legal status of the constitutional court's endorsement, which was not a sentence but merely a statement (comunicado), is contested (Los Tiempos 2020), it did lend procedural legitimacy to the transition. 
At the level of policy-making, the (unelected) interim government has taken a whole series of political decisions that reverse the political course taken by the (elected) predecessor government. In the area of foreign policy, for instance, the government immediately broke diplomatic relations with Cuba and Venezuela, recognized Juan Guaidó as the president of Venezuela, and rapidly moved to resume full diplomatic relations with the US by appointing an ambassador to the US and inviting USAID back to Bolivia (see BBC 2019; Farthing 2020: 11). In the area of economic policy, the steps to dismantle the state-centered development model established by the MAS government have so far been more gradual in nature; but the composition of the government and its close ties with Bolivia's traditional economic elites leave little doubts about the direction it is taking. With the COVID-19 pandemic, the interim government exercises overwhelming executive power, as do incumbent governments all across the world. Yet, Áñez has to deal with a parliament controlled by the MAS, which was able to set a date for the new elections (6 September, see below) and frustrate the president's attempt to postpone general elections even further. For the state of Bolivian democracy, this division of power is good news given that Áñez is both an unelected interim president with precarious democratic legitimacy and a candidate in the forthcoming presidential elections.

Furthermore, the Áñez government has embarked on what critics, including the UN High Commissioner for Human Rights, Michelle Bachelet, see as a political persecution of former MAS representatives (see Farthing 2020: 10-11; La Razón 2020a; Levitsky and Murillo 2020: 7-8; Moldiz 2020: 30-31, 107-118). ${ }^{20}$ While the government justifies these measures as merely an attempt to bring to justice those that have committed crimes, the very rhetoric of key government representatives confirms its explicitly political nature. Key examples include the new Minister of the Interior, Arturo Murillo, who publicly announced a "hunt" (cacería) for selected MAS politicians (Moldiz 2020: 108-109) or Áñez herself, who warned of a potential return of "the savages" (los salvajes) (Mayorga 2020: 1-2). As a result, serious doubts exist as to whether the government will be permitting the MAS from competing under reasonably fair conditions in the forthcoming elections.

\section{An Outlook on the (Postponed) New Elections}

Originally, new general elections had been scheduled for 3 May 2020. However, in response to the COVID-19 pandemic and the lockdown of the country mandated by the government in order to contain the spread of the coronavirus,

20 The repressive response to pro-MAS protests in the immediate context of the forced resignation of Morales is more difficult to assess. On the one hand, it remains contested what precisely happened. On the other, from the perspective of the interim government and its supporters, the measures adopted were seen as necessary to "pacify" the situation in order to move towards new elections. International observers, however, have criticized what they regard as disproportionately repressive behavior on the part of the security forces (see Farthing 2020: 9-10; IACHR 2019; La Razón 2020a; Levitsky and Murillo 2020: 7-8). 
they were postponed. In June, after her attempt to even further postpone the elections had met with the united resistance from the parliamentary majority, the electoral tribunal and her main contenders, interim president Áñez agreed to promulgate the law fixing the elections for 6 September (La Razón 2020c).

At the time of finalizing this manuscript (June 2020), seven presidential tickets (binomios) were competing for the presidency:

- The MAS, led by its official campaign chief Evo Morales, has decided to run with long-standing minister of economy Luis Arce and former foreign minister David Choquehanca.

- Comunidad Ciudana (CC) stuck with its previous ticket: former president Carlos Mesa and Gustavo Pedraza, who served as his minister of sustainable development and planning in 2004-2005.

- Current interim president Jeanine Áñez is the candidate of JUNTOS. This newly created alliance brings together Áñez's party, Movimiento Demócrata Social (Demócratas) from Santa Cruz, the party of her vice-presidential candidate Samuel Doria Medina (Unidad Nacional - UN) as well as the party of La Paz mayor Luis Revilla, Soberania y Libertad (Sol.bo). In the 2019 elections, both UN and Sol.bo had supported the candidacy of Carlos Mesa.

- Already in November 2019, Luis Fernando Camacho had quit the leadership of the Comité Pro Santa Cruz with a view to running for the elections. His vice-presidential candidate is another former civic committee leader, Marco Pumari from Potosí. Their party alliance CREEMOS brings together the two small parties Partido Demócrata Cristiano (PDC) and Unidad Cívica Solidaridad (UCS).

- Chi Hyun Chung, an evangelical pastor who scored a surprising $9 \%$ in the 2019 elections (see Table 1), is the official candidate of the Frente Para la Victoria (FPV). His candidacy, however, was uncertain, given that vice-presidential candidate Jessmy Barrientos was disqualified by the TSE and the FPV was trying to replace Chi by another candidate.

- Jorge (Tuto) Quiroga, another former president and long-standing senator, runs together with Tomasa Yarhui, his former minister in 2002, for the alliance Libertad y Democracia (Libre 21), which includes the remainders of the traditional party Movimiento Nacionalista Revolucionario (MNR).

- Finally, Feliciano Mamani and Ruth Nina are the presidential candidates of the Partido de Acción Nacional Boliviano (PAN-BOL).

These seven parties or party alliances are also the political forces competing for seats in the two-chamber parliament, in addition to Acción Democrática Nacionalista (ADN), the recently revived party of the deceased former dictator and elected president Hugo Banzer. Furthermore, indigenous organizations (organizaciones de las naciones y pueblos indígena originario campesinos) have presented 
candidates for the seven special reserved seats provided for by the country's constitution.

Before the COVID-19 pandemic hit Bolivia, opinion polls suggested that MAS candidate Arce would almost certainly make it to the second round and even had a chance of winning the presidential elections in the first round (see Table 3). Jeanine Añez, clearly benefiting from her role as interim president, was catching up with Mesa, while Camacho was almost continuously losing ground. ${ }^{21}$

Table 3. Results of Election Polls (Valid Votes) November 2019-March 2020

\begin{tabular}{lccccc}
\hline & Nov & Dec & Jan & Feb & Mar \\
& 2019 & 2019 & 2020 & 2020 & 2020 \\
\hline Luis Arce \& David Choquehuanca (MAS-IPSP) & $20 \%$ & $25 \%$ & $31 \%$ & $36 \%$ & $40 \%$ \\
Carlos Mesa \& Gustavo Pedraza (CC) & $18 \%$ & $21 \%$ & $21 \%$ & $20 \%$ & $22 \%$ \\
Jeanine Áñez \& Samuel Doria Medina (JUNTOS) & $0 \%$ & $10 \%$ & $15 \%$ & $20 \%$ & $20 \%$ \\
Luis Fernando Camacho \& Marco Pumari (CREEMOS) & $20 \%$ & $13 \%$ & $21 \%$ & $12 \%$ & $9 \%$ \\
\hline
\end{tabular}

Source: Bolivia Electoral, https:/ /2020.boliviaelectoral.com/. Monthly average of existing election polls; valid votes only; last update: 16 March 2020.

Given the postponement of the elections and the general uncertainty that comes with the COVID-19 crisis, much can still happen to the voters' preferences. Still, survey results at least suggest three issues: First, the MAS continues to receive support from an important, if no longer majoritarian part of the population. As a party, it has proven a remarkable capacity to remain relatively united, even if this unity may well begin to crumble after the elections. Second, the former opposition to the MAS continues as divided and fragmented as before. This fragmentation will most probably characterize the near future of Bolivian democracy, even if some type of tactical alliance should emerge - either before the first or, at the latest, before the second round - in order to prevent the MAS from returning to the presidency. Third, any next president will most likely be confronted with a parliament in which his or her party (alliance) does not hold a majority.

In sum, the risks of stalemates, mutual blockades and open conflict between the different political forces as well as between government and parliament are high. In the Bolivian context, such political conflicts are usually accompanied by competing processes of mobilization on the streets. Given the foreseeably difficult economic situation, this suggests that even successful and broadly accepted elections may give way to yet another period of political instability and

21 Camacho's alliance with Pumari suffered right from the start "when a leaked tape revealed Pumari supposedly asking Camacho for $\$ 250,000$ and profits from customs operations to secure the spot as his vice presidential running mate" (Farthing 2020: 10). 
intense social conflict. When considering the current level of polarization and the experience of the October 2019 elections, however, this is the optimistic scenario. Neither can we take for granted that the MAS will accept a defeat in future presidential elections, nor can we be sure that the alliance of sociopolitical forces that is politically controlling and socially sustaining the current government would be willing to hand the presidency back to the MAS. In the case of a contested MAS defeat, the political struggle would again be shifted to the streets, with the MAS and its supporters trying to put pressure on and destabilize a government that, on its part, might use its electoral legitimacy to respond with repression and judicial prosecution. In the case of a disputed MAS victory, we might even see the return of the classical coup, sustained by the traditional political and economic elites, the security forces and the urban middle classes, who would then openly violate basic democratic principles - even if, of course, rhetorically justified as a defense of democracy.

During the last 35 years, Bolivian democracy has been characterized by a remarkable capacity to eventually solve even severe sociopolitical crises in relatively inclusive and peaceful ways. But there is no denying that the future of democracy and social peace in post-Evo Bolivia is currently at stake.

\section{REFERENCES}

Arze Vargas, Carlos, and Javier Gómez. 2013. “Bolivia: ¿El ‘Proceso de Cambio’ nos Conduce al Vivir Bien?" In Promesas en su Laberinto. Cambios y Continuidades en los Gobiernos Progresistas de América Latina, edited by Carlos Arze, Javier Gómez, Pablo Ospina, and Víctor Álvarez. La Paz: CEDLA, 45-176.

Barrios Suvelza, Franz. 2017. “¿Qué Tipo de Régimen Político Impera en los Países del Nuevo Constitucionalismo Latinoamericano? Indicaciones Desde el Caso Boliviano." Revista Latinoamericana de Política Comparada 12: 71-101.

Barrios Suvelza, Franz. 2019, 14 November: "Por Qué No Hubo Golpe de Estado en Bolivia." Página SIETE. Retrieved on March 20, 2020 from https://www.paginasiete.bo/opinion/2019/11/14/por-que-no-hubo-golpe-de-estado-en-bolivia-237353.html.

BBC. 2019, 27 November. "Bolivia Crisis: Interim Leader Appoints First US Envoy in 11 Years." Retrieved on April 24, 2020 from https://www.bbc.com/news/world-latin-america-50568101.

Brockmann Quiroga, Erika. 2020. “Tentativa de toma gradual del poder: Prorroguismo fallido y transiciones." In Crisis y cambio político en Bolivia. Octubre y noviembre de 2019, edited by Fernando Mayorga. La Paz: CESU-UMSS, 29-60.

Chiasson-Le Bel, Thomas, and Manuel Larrabure. 2019. "Latin America's Changing Balance of Class Forces: An Introduction." European Review of Latin American and Caribbean Studies 108: 87-107.

Chumacero, Rómulo A. 2019. "El Camaleón, el Mutante y Houdini: Resultados de las Elecciones en Bolivia." Retrieved on March 17, 2020 from http://rchumace.econ.uchile. $\mathrm{cl} /$ papers/cmh.pdf.

Crisis Group. 2019, 13 November. "Keeping Violence in Check after Bolivia's Political Rupture." Retrieved on November 14, 2019 from https://www.crisisgroup.org/latin-americacaribbean/andes/bolivia/keeping-violence-check-after-bolivias-political-rupture.

Curiel, John, and Jack R. Williams. 2020, 27 February. "Bolivia Dismissed its October Elections as Fraudulent. Our Research Found No Evidence of Fraud." Washington Post: Monkey Cage. Retrieved on February 28, 2020 from https://www.washingtonpost.com/ 
politics / 2020/02/26/bolivia-dismissed-its-october-elections-fraudulent-our-research-found-no-reason-suspect-fraud.

Escobari, Diego, and Gary A. Hoover. 2019. "Evo Morales and Electoral Fraud in Bolivia: A Natural Experiment Estimate." Retrieved on March 18, 2020 from https://faculty. utrgv.edu/diego.escobari/fraud.pdf.

EU (European Union). 2019. "Bolivia 2019: Informe Final. Elecciones 20 de Octubre de 2019." Retrieved on March 17, 2020 from https://www.uetrabajandojuntos.org/wp-content/uploads/2019/12/EU-EEM-BOL-2019-FR-ES.pdf.

Farthing, Linda. 2020. "In Bolivia, the Right Returns with a Vengeance." NACLA Report on the Americas 52(1): 5-12.

Grandin, Greg. 2019, 18 December. "What 'The New York Times' Got Wrong on Bolivia." The Nation. Retrieved on March 20, 2020 from https://www.thenation.com/article/ archive/bolivia-times-morales-coup.

Hochstetler, Kathryn. 2006. "Rethinking Presidentialism: Challenges and Presidential Falls in South America." Comparative Politics 38(4): 401-418.

IACHR (Inter-American Commission on Human Rights). 2019, 10 December. "The IACHR Presents its Preliminary Observations Following its Visit to Bolivia". Retrieved on April 6, 2020 from https://www.oas.org/en/iachr/media_center/PReleases/2019/321.asp.

Idrobo, Nicolás, Dorothy Kronick, and Francisco Rodríguez. 2020. "Do Shifts in Late-Counted Votes Signal Fraud? Evidence From Bolivia." Retrieved on June 8, 2020 from https:/ / papers.ssrn.com/sol3/papers.cfm?abstract_id=3621475.

Johnston, Jack, and David Rosnick. 2020. "Observing the Observers: The OAS in the 2019 Bolivian Elections." Retrieved on March 16, 2020 from https://www.cepr.net/wp-content/uploads/2020/03/bolivia-2020-3.pdf.

Juárez, Ivone. 2019, 3 December. "Al Menos 15 Personas Hicieron Posible que la Paz Volviera a Bolivia." Página SIETE. Retrieved on April 6, 2020 from https:/ /www.paginasiete.bo/gente/2019/12/3/al-menos-15-personas-hicieron-posible-que-la-paz-volviera-bolivia-239234.html.

La Razón. 2019a, 13 November. “Áñez Anuncia Derogación de la Repostulación y Pide a Funcionarios Poner Cargos a Disposición." Retrieved on November 14, 2019 from https://www.la-razon.com/nacional/Tareas-Anez-derogacion-repostulacion-funcionarios-disposicion-cargo_0_3257074306.html.

La Razón. 2019b, 24 November. "Rige la Ley para las Elecciones sin Evo con Plazo Máximo de 120 Días tras la Convocatoria." Retrieved on November 24, 2019 from https:/ /www. la-razon.com/index.php?_url=/nacional/bolivia-elecciones-ley-plazo-promulgacion-norma-tse_0_3263673607.html.

La Razón. 2020a, 19 February. "Cuatro Organismos Internacionales Denunciaron Violación de DDHH y Persecución en Bolivia." Retrieved on March 2, 2020 from https:// la-razon.com/nacional/CELAG-denunciaron-DDHH-persecucion-Bolivia-elecciones-violencia_0_3321867801.html.

La Razón 2020b, 19 February. “La Fiscalía Abre Investigación Contra Morales por Denuncia de Fraude Electoral." Retrieved on March 27, 2020 from http:/ /www.la-razon.com/ nacional/evo-morales-fiscalia-delitos-electorales-bolivia-carlos-mesa_0_3315868441. html.

La Razón 2020c, 21 June. "Áñez Decide Promulgar la Ley de Elecciones y Dice que lo Hace 'Presionada' por Mesa y el MAS." Retrieved on June 23, 2020, from https:/ /www. la-razon.com/nacional/2020/06/21/luego-de-12-dias-de-vaivenes-anez-decidepromulgar-la-ley-que-fija-elecciones-el-6-de-septiembre.

Laserna, Roberto. 2019, 5 December. "No Fue Golpe de Estado." La Razón. Retrieved on March 27, 2020 from http://www.la-razon.com/suplementos/animal_politico/golpe-animal-politico_0_3270272959.html.

Layme, Beatriz. 2019, 22 November. "Pese a Radicales del MAS, se Perfila Pacto para Comicios sin Evo Morales." Página SIETE. Retrieved on April 6, 2020 from https:/ /www. 
paginasiete.bo/nacional/2019/11/22/pese-radicales-del-mas-se-perfila-pacto-para-comicios-sin-evo-morales-238180.html.

Levitsky, Steven, and María Victoria Murillo. 2020. "La Tentación Militar en América Latina." Nueva Sociedad 285: 4-11.

Long, Guillaume, David Rosnick, Cavan Kharrazian, and Kevin Cashman. 2019. "What Happened in Bolivia's 2019 Vote Count? The Role of the OAS Electoral Observation Mission." Retrieved on November 9, 2019 from http://cepr.net/images/stories/reports/bolivia-elections-2019-11.pdf.

Los Tiempos. 2020. "Magistrado Afirma Que el Comunicado del TCP Sobre la Sucesión de Áñez No Tiene Valor Legal." Retrieved on February 14, 2020 from https://www. lostiempos.com/actualidad/pais/20200214/magistrado-afirma-que-comunicado-del-tcp-sucesion-anez-no-tiene-valor-legal.

MAS (Comité Político del MAS). 2019, 11 November. "Resistir, Para Mañana Volver a Combatir." Retrieved on March 20, 2020 from https://rebelion.org/resistir-para-manana-volver-a-combatir.

Mayorga, Fernando. 2016. "Bolivia: Ciclo Electoral 2014-2015 y Mutaciones en el Campo Político." In Elecciones y Legitimidad Democrática en América Latina, edited by Fernando Mayorga. Buenos Aires: CLACSO, 205-234.

Mayorga, Fernando. 2020. "Derrota política del MAS y proyecto de restauración oligárquico-señorial." In Crisis y cambio político en Bolivia. Octubre y noviembre de 2019, edited by Fernando Mayorga. La Paz: CESU-UMSS, 1-28.

Mebane, Walter R. 2019. "Evidence Against Fraudulent Votes Being Decisive in the Bolivia 2019 Election." Retrieved on March 27, 2020 from http://www-personal.umich. edu/ wmebane/Bolivia2019.pdf.

Mesa Gisbert, Carlos D. 2020, 26 January. "Una Decisión Equivocada." Página SIETE. Retrieved on March 20, 2020 from https://www.paginasiete.bo/opinion/carlos-d-mesa/2020/1/26/una-decision-equivocada-244591.html.

Minoldo, Sol, and Rodrigo Quiroga. 2020, 4 March. “¿Hubo Fraude en las Elecciones de Bolivia?" Retrieved on 1 April 2020 from https://www.cenital.com/2020/03/03/hubo-fraude-en-las-elecciones-de-bolivia-/64744.

Moldiz Mercado, Hugo. 2020. Golpe de Estado en Bolivia. La Soledad de Evo Morales. Havanna: Ocean Sur.

Molina, Fernando. 2019. "Bolivia: ¿Golpe o (Contra)Revolución?" Nueva Sociedad. Retrieved on 15 November 2019 from https://nuso.org/articulo/bolivia-golpe-o-contrarevolucion.

Natanson, José 2019, 12 November. "Tres Conclusiones Sobre el Golpe de Estado Contra Evo Morales." Página 12. Retrieved on March 20, 2020 from https:/ /www.pagina12.com. ar/230488-tres-conclusiones-sobre-el-golpe-de-estado-contra-evo-morale.

Newman, John. 2020. "The OAS Conclusions About the Election Integrity of the Bolivian Election are Correct". Retrieved on June 9, 2020 from https://firebasestorage.googleapis.com/v0/b/derechadiario.appspot.com/o/files\%2F_c1i4zvr-Bolivia\%20 2019\%20elections\%20Newman.pdf.

Nooruddin, Irfan. 2020, 10 March. "Yes, Bolivia's 2019 Election was Problematic. Here's Why." The Washington Post: Monkey Cage. Retrieved on March 27, 2020 from http://www. washingtonpost.com/politics/2020/03/10/yes-bolivias-2019-election-was-problematic-heres-why.

Nugent, Ciara. 2019, 15 November. “How Bolivia's Evo Morales Was Brought Down With the Help of an Obscure Conservative With a Bible." Time. Retrieved on April 17, 2020 from https: / / time.com/5728279/luis-fernando-camacho-bolivia.

OAS (Organization of American States). 2019a, 21 October. "Statement of the OAS Electoral Observation Mission in Bolivia." Retrieved on April 6, 2020 from https://www.oas. org/en/media_center/press_release.asp?sCodigo=E-085/19. 
OAS. 2019b, 10 November. "Comunicado del Secretario General sobre Informe Preliminar Auditores Proceso Electoral en Bolivia.". Retrieved on November 11, 2019 from https:/ / www.oas.org/es/centro_noticias/comunicado_prensa.asp?sCodigo=C-100/19.

OAS. 2019c. "Electoral Integrity Analysis: General Elections in the Plurinational State of Bolivia, October 20, 2019: Final Report." Retrieved on February 10, 2020 from http:// www.oas.org/fpdb/press/Audit-Report-EN-vFINAL.pdf.

Página SIETE. 2019, 26 November. “COB y Pacto de Unidad Firman Acuerdo con el Gobierno." Retrieved on April 6, 2020 from https:/ /www.paginasiete.bo/nacional/2019/11/26/ cob-pacto-de-unidad-firman-acuerdo-con-el-gobierno-238554.html.

Powell, Jonathan M., and Clayton L. Thyne. 2011. "Global Instances of Coups from 1950 to 2010: A New Dataset." Journal of Peace Research 48(2): 249-259.

Rosnick, David. 2019. "Unnatural Claims in a 'Natural Experiment': Escobari and Hoover on the 2019 Bolivian Elections." Retrieved on March 27, 2020 from https:/ /cepr.net/ wp-content/uploads/2019/12/escobari-hoover-bolivia-2019-12.pdf.

Rosnick, David. 2020. “The Ends Don't Justify the Means: Yet Another Analysis Fails to Support the OAS' Delegitimization of Bolivian Elections." Retrieved on June 9, 2020 from https:/ / cepr.net/report/the-ends-dont-justify-the-means.

Santos, Boaventura de Sousa. 2019. "Evo Morales: el Indio Fuera de Lugar." Retrieved on March 20, 2020 from https:/ / rebelion.org/docs/263113.pdf.

Shifter, Michael. 2019, 17 November. "En Términos muy Técnicos lo de Bolivia es un Golpe." La República. Retrieved on November 20, 2019 from https://larepublica.pe/domingo/2019/11/17/michael-shifter-en-terminos-muy-tecnicos-lo-de-bolivia-es-un-golpe.

Stefanoni, Pablo. 2020. "Las Lecciones Que Nos Deja Bolivia." Nueva Sociedad. Retrieved on March 13, 2020 from https://nuso.org/articulo/Bolivia-Evo-Morales-elecciones.

Vaca, Mery. 2019, 17 November. "La Historia No Contada de la Salida de Evo Morales y la Sucesión de Áñez". Página SIETE. Retrieved on March 23, 2020 from https://www. paginasiete.bo/nacional/2019/11/17/la-historia-no-contada-de-la-salida-de-evomorales-la-sucesion-de-anez-237603.html\#!.

Vacaflores, Daniel. 2019. "Sobre el Cuestionamiento al Fraude en las Elecciones Nacionales Bolivianas de 2019." Retrieved on April 3, 2020 from https://www.academia. edu/41095519/Sobre_el_cuestionamiento_al_fraude.

Valdivia, Walter D., and Diego Escobari. 2020. "Bolivia's Electoral Fraud Reckoning." Retrieved on March 18, 2020 from https://www.project-syndicate.org/commentary/ evo-morales-bolivia-presidential-election-fraud-by-walter-d-valdivia-and-diego-escobari-2020-03.

Valenzuela, Arturo. 2004. "Latin American Presidencies Interrupted." Journal of Democracy 15(4): 5-19.

Villegas, Edgar et al. 2019. "Informe Sobre Irregularidades Identificadas en las Elecciones en Bolivia Realizadas el 20 de Octubre de 2019." Retrieved on April 3, 2020 from https://www.yumpu.com/es/document/read/62907943/conade-informe-irregularidades-elecciones-2019.

Wolff, Jonas. 2019. "The Political Economy of Bolivia's Post-Neoliberalism: Policies, Elites, and the MAS Government." European Review of Latin American and Caribbean Studies 108: 109-129.

Zegada Claure, María Teresa. 2019. “El Escenario Boliviano en 2018: Estabilidad Económica e Incertidumbre Institucional." Revista Ciencia Política 39(2): 147-164.

Received: April 27, 2020

Accepted: June 30, 2020 
Jonas Wolff is executive board member and head of the research department "Intrastate Conflict" at the Peace Research Institute Frankfurt (PRIF). His research focuses on the transformation of political orders, contentious politics, international democracy promotion, and Latin American politics. Recent publications include The negotiation of democracy promotion (Special Issue of Democratization, 2019, co-edited with AE Poppe and J Leininger) and Socioeconomic Protests in MENA and Latin America (Palgrave Macmillan, 2020, co-edited with I Weipert-Fenner). E-mail: wolff@hsfk.de 